\section{Use of Equine Pituitary Extract (EPE) in low doses to induce double ovulation in mares}

\author{
Utilização de Extrato de Pituitária Equina (EPE) em baixas \\ doses para induzir dupla ovulação em éguas
}

\author{
Marcus André Ferreira Sáw*, Gabriel de Oliveira Santos², Luciana Lima Bezerra³, Marcela Poerner Moreno', \\ Celso Guimarães Barbosa ${ }^{4}$, Marco Antônio Alvarenga ${ }^{5}$ \& Júlio César Ferraz Jacob ${ }^{1}$ \\ 'Veterinary, DSc. Programa de Pós-graduação em Medicina Veterinária - PPGMV, Instituto de Veterinária, Universidade Federal \\ Rural do Rio de Janeiro - UFRRJ, Seropédica, RJ, Brasil \\ ² Veterinary, MSc. Departamento de Medicina Animal, Universidade Federal do Rio Grande do Sul - UFRGS, Porto Alegre, RS, \\ Brasil \\ ${ }^{3}$ Veterinary, DSc. Universidade Federal de Viçosa - UFV, Viçosa, MG, Brasil \\ ${ }^{4}$ Veterinary, DSc. Departamento de Matemática, Universidade Federal Rural do Rio de Janeiro - UFRRJ, Seropédica, RJ, Brasil \\ ${ }^{5}$ Veterinary, PhD. Departamento de Reprodução Animal e Radiologia Veterinária, Faculdade de Medicina Veterinária e \\ Zootecnia - FMVZ, Universidade Estadual Paulista "Júlio de Mesquita Filho" - UNESP, Botucatu, SP, Brasil
}

\begin{abstract}
The aim of this study was to evaluate the effect of treatment using low doses of EPE on rates of ovulation and embryo recovery. Eight mares were used in this way: first cycle $(\mathrm{n}=8)$ - control group (untreated): second cycle $(n=8)$ - treated group using $8.0 \mathrm{mg}$ of EPE, bid, until at least two follicles reached $\geq 35 \mathrm{~mm}$ diameter. At this moment, was administered 1000 IU hCG, E.V., as ovulation agent. The embryos recovery were performed eight days after detection of second ovulation. Mares received 5.0 mg PGF ${ }_{2 \alpha^{\prime}}$ I.M. on D8. The percentage of mares that showed two or more ovulations was higher $(\mathrm{p}<0.01)$ for the treated group $(7 / 8,87.5 \%)$ than the control group $(1 / 8,12.5 \%)$. The rate of recovered embryos per ovulation did not show statistical difference $(\mathrm{P}>0.05)$ between the treated $(11 / 16,68.8 \%)$ and control $(6 / 9,66.6 \%)$ groups. The results of this study allow concluding that treatment using low doses of EPE increased the incidence of multiple ovulations and provided greater recovery embryos rate.
\end{abstract}

Keywords: multiple ovulations, ovulation rate, embryo recovery, ovarian physiology.

\section{Resumo}

O objetivo do presente estudo foi avaliar o efeito do tratamento utilizando baixa dose de EPE sobre as taxas de ovulação e recuperação embrionária. Foram utilizadas oito éguas da seguinte forma: primeiro ciclo ( $n=8)$ - grupo controle (não tratadas); segundo ciclo (n=8) - grupo tratado utilizando 8,0 mg de EPE, bid, até que pelo menos dois folículos atingissem diâmetro $\geq 35 \mathrm{~mm}$. Neste momento foi administrado 1000 UI, EV., de hCG como indutor de ovulação. As coletas dos embriões foram realizadas oito dias após detecção da segunda ovulação. As éguas receberam 5,0 mg de $\mathrm{PGF}_{2 \alpha^{\prime}}$ I.M. no D8. A porcentagem de éguas com duas ou mais ovulações foi maior $(\mathrm{p}<0,01)$ para o grupo tratado $(7 / 8,87,5 \%)$ do que para o grupo controle $(1 / 6$, 12,5\%). O número de embriões recuperados por ovulação não apresentou diferença estatística $(P>0,05)$ entre os grupos tratado (11/16, 68,8\%) e controle (6/9,66,6\%). Os resultados do presente estudo permitem concluir que o tratamento utilizando baixa dose de EPE aumentou significativamente a incidência de múltiplas ovulações e proporcionou maior taxa de recuperação de embriões.

Palavras-Chave: múltiplas ovulações, taxa de ovulação, recuperação embrionária, fisiologia ovariana.

\section{Introduction}

Equine reproduction biotechnologies have presented great progress in the last decades. Embryo transfers (E.T) in horses has been the main resource in order to improve genetic gain in equine. The induction of multiple ovulations has been a resource increasing the number of embryos produced. According to Squires et al. (2003) in mares that presenting natural ovulation, embryos recovery is around 50\% for ovulation. On the other hand, embryos recovery is higher in mares spontaneously presenting two or three ovulations. However, the number of embryos recovered for each ovulation in mares induced to multiple ovulations has still been low and close

\section{B] M \\ Brazilian Journal of Veterinary Medicine \\ p-ISSN 0100-2430 \\ e-ISSN 2527-2179 \\ ○}

How to cite: Sá, M. A. F., Santos, G. O., Bezerra, L. L., Moreno, M. P., Barbosa, C. G., Alvarenga, M. A., \& Jacob, J. C. F. (2017). Use of Equine Pituitary Extract (EPE) in low doses to induce double ovulation in mares. Brazilian Journal of Veterinary Medicine, 39(2), 115-119. doi: 10.29374/2527-2179. bjvm034216

Financial support: Fundação Carlos Chagas Filho de Amparo à Pesquisa do Estado do Rio de Janeiro (FAPERJ) process E-26/110.219/2008.

Conflict of interests: No conflict of interests declared concerning the publication of this article.

Received: July 22, 2016.

Accepted: November 13, 2016.

The study was carried out at Universidade Federal Rural do Rio de Janeiro - UFRRJ, Seropédica, RJ, Brasil.

\title{
*Correspondence
}

Marcus André Ferreira Sá

Departamento de Reprodução e Avaliação Animal, Universidade Federal Rural do Rio de Janeiro - UFRRJ

BR 465, km 7

CEP 23890-000 - Seropédica (RJ), Brasil E-mail:marcus.ferreira85@hotmail.com 
to that one presented by mares with natural ovulation, around 0.5 embryos. Several products have been employed in order to increase follicles number for mares ovulation as Porcine Follicle Stimulating Hormone (p-FSH) (Cullingford et al., 2010), Equine Chorionic Gonadotrofin (ECG) and Gonadotropin Releasing Hormone (GnRH) (Farquhar et al., 2000), Equine Pituitary Extract (EPE) (Alvarenga et al., 2001, 2008), purified Extract of Equine Follicle Stimulating Hormone (e-FSH), (Köllmann et al., 2008) and more recently, Deslorelin Acetate (Azevedo et al., 2015). Due to the fact that results have widely varied, research is directed to protocols using EPE and FSH, re-FSH and re-LH combination and Deslorelin Acetate (Bertozzo et al., 2012). Evaluating results obtained from EPE literature it might be concluded that some progress has been reached in the last decades. However, the more the ovary is stimulated, the lower is embryos recovery (Logan et al., 2007). Thus, this study aimed to evaluate the effect of the treatment employing low EPE doses in ovulation rates and embryos recovery.

\section{Material and methods}

Eight mares presenting body condition score three (scale from one to five), regularly cycling, age between four and 15 years old, during two consecutive estrus cycles was used. Mares were kept in paddocks with pasture, ad libitum fresh water and daily supplemented with concentrated feed. The ovarian activity of the mares was daily monitored during estrus by palpation and transrectal ultrasound by Sonovet 2000 equipment with the $5.0 \mathrm{MHz}$ linear transducer.

Estrus cycles of each mare as followed: first cycle $(n=8)$ - control group; second cycle $(n=8)$ - treated group using 8.0mg EPE bid, until at least two follicles reaching $\geq 35 \mathrm{~mm}$ diameter were used. At this moment, intravenous 1000 IU human Chorionic Gonadotrophin (hCG, Chorulon ${ }^{\circledR}$ ) as ovulation inducer was administered. EPE treatment was initiated around D8 after ovulation detection (D0) when 22mm diameter follicles were detected. Mares received intramuscular 5.0mg Dinoprost Tromethamine (Lutalyse ${ }^{\circledR}$ ) at D8.

All mares were inseminated with fresh or cooled semen from proven fertility stallions from $24 \mathrm{hs}$ after ovulation induction or every $48 \mathrm{hs}$ till ovulations detected. Uterine flushes for embryo recovery were performed eight days after the second ovulation detection. For averages comparison Student's test at 5\% was applied.

\section{Results}

The mean diameter of the largest follicle at the beginning of the treatment reached $18.0 \pm 4.64 \mathrm{~mm}$. The average at the daily growth of the dominant follicle in the treated group was $3.33 \mathrm{~mm} /$ day and $3.0 \mathrm{~mm} /$ day in the control group, no significant difference was reported ( $p>0.05$ ). Machado et al. (2003) reported lower follicular growth daily rates (2.2mm/day) in mares in EPE treatment.

Percentage of mares with two or more ovulations was higher $(\mathrm{p}<0.01)$ in the treated group $(87.5 \%, 7 / 8)$ than in the control one $(12.5 \%, 1 / 8)$. No significant difference ( $p>0.05)$ between groups in the follicular period (days) from the first application day up to ovulation day was reported. Embryo recovery number by cycle was higher in the treated group 11/8 than in the control group (6/8), but no difference between groups ( $\mathrm{p}=0.0588$ ). No difference $(\mathrm{p}>0.05)$ between groups (68.8\%, 11/6 treated group; 66.6\%, 6/9 control group) for embryos recovery rate was reported (Figure 1). Treatment mean duration (days) until at least two follicles reaching the pre-ovulatory size (35mm diameter) was $8.750 \pm 1.282$ (Table 1 ).

\section{Discussion}

Data from the literature are diversified when considering a number of days between prostaglandin administration to the subsequent ovulation. In this survey, the time between prostaglandin and subsequent ovulation was $8.7 \pm 1.3$ days for treated group and $8.6 \pm 1.5$ for control one. This result is in agreement with those ones from Dippert et al. (1994) reporting 7.0 days and Alvarenga et al. (2001) with 8.3 days.

From eleven embryos recovered in the treated group, nine as grade I and only one as grade II (McCue \& Squires, 2015) were classified, as well as no statistically different ( $p>0.05$ ) from the control group with all the six embryos recovered presenting grade I. Embryo development grade was consistent with the gestational age at D8 (blastocyst or expanded blastocyst) in both groups. 


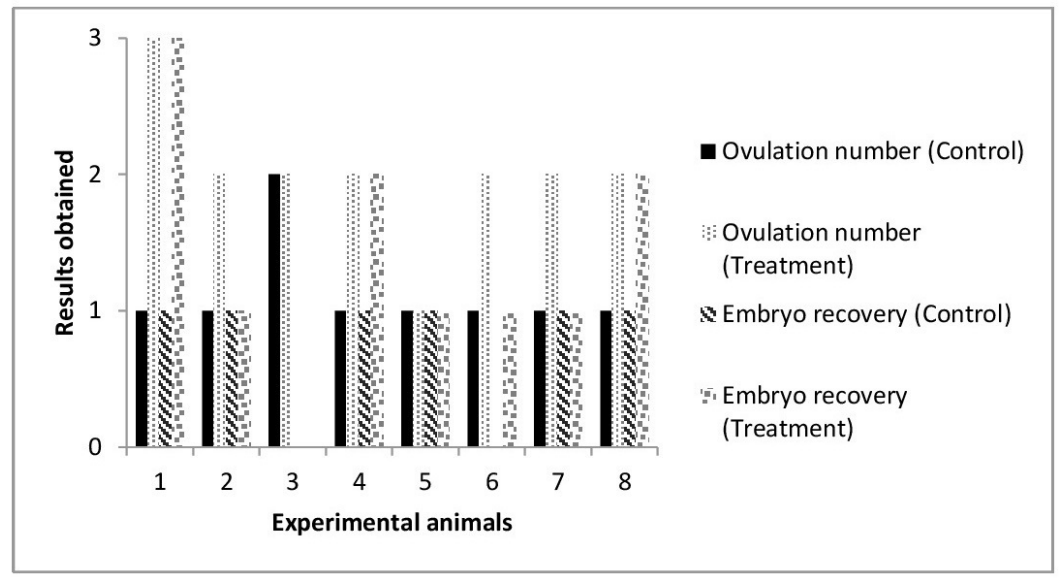

Figure 1. Reproductive parameters (ovulation number and embryo recobery) about control and treated groups.

Table 1. Reproductive parameters obtained in control and EPE groups.

\begin{tabular}{cccc}
\hline & Control group & & Treated groups \\
\cline { 2 - 3 } Parameters & $\mathbf{( n = 8 )}$ & $\mathbf{( n = 8 )}$ \\
\hline Treatment duration (day) & - & $6.250 \pm 0.886$ \\
Follicles $\geq 35 \mathrm{~mm}$ & $9 / 8^{\mathrm{b} *}$ & $14 / 8^{\mathrm{a}}$ \\
Follicular period duration (days) & $8.667 \pm 1.506^{\mathrm{a}}$ & & $8.750 \pm 1.282^{\mathrm{a}}$ \\
Ovulation/cycle & $9 / 8^{\mathrm{a}}$ & $16 / 8^{\mathrm{a}}$ \\
Mares with two or more ovulations (\%) & $1 / 8(12.5)^{\mathrm{b}}$ & $7 / 8(87.5)^{\mathrm{a}}$ \\
Embryos/cycle & $5 / 8^{\mathrm{a}}$ & $11 / 8^{\mathrm{a}}$ \\
Embryos/ovulation (\%) & $6 / 9(66.6)^{\mathrm{a}}$ & $11 / 16(68.8)^{\mathrm{a}}$ \\
\hline
\end{tabular}

*Different letters for the same parameter statistically differ $(\mathrm{p}<0.05)$.

From the eight mares treated, (six presenting two ovulations and three ones with unilateral ovulations), one presenting triple ovulation (bilateral ovulations) and only one presenting single ovulation did not react to the treatment were evaluated (Table 1). Ginther \& Pierson (1989) reported no significant difference between uni or bilateral ovulations, as well as Squires et al. (1987) reporting 49.7\% and 50.3\%.

In this study, EPE the doses used was able stimulating ovarian activity in mares, where the percentage of mares presenting multiple ovulations in EPE group was 87.5\% (7/8) while in the control group was $12.5 \%$ (1/8). Similar results were reported by Douglas (1979) demonstrating 75\% superovulated mares in EPE treatment. Scoggin et al. (2002) reported from 60 to 100\% multiple ovulations using different EPE protocols. Bonin et al. (2010) reported 65\% multiple ovulations in elderly mares treated with EPE.

In this research, an average of 1.375 embryos/cycle was obtained, but no difference ( $\mathrm{p}=0.0588$ ) than 0.75 in control group (Table 1). In no stimulated mares, Squires et al. (2003) reported 0.65 embryos/cyles/130 mares. Other authors reported embryos recovery rate around 1 to 2 embryos/cycle in multiple ovulations (Douglas, 1979; Woods \& Ginther, 1983; McCue, 1996; Machado et al., 2003).

In this study, protocol applied for inducing double or triple ovulation presented better results in regard to embryos recovery/cycle than in ovulation, providing more than twice the number of embryos/cycle.

No statistical difference (p> 0.05) for control groups $(66.69 \%, 6 / 9)$ in relation to embryos recovery/ovulation for treated groups (68.8\%,11/16) was reported. However, embryos/recovery rate was higher than those ones reported by Alvarenga et al. (2001, 2008), (49 and 40\%, respectively). 
Scoggin et al. (2002), (43.2\%) and Machado et al. (2003), (26\%) in mares treated with 25mg EPE. However, it was close to that one reported by Nagao et al. (2012), reaching 61.7\% (63/102) with $100 \mu \mathrm{g}$ Deslorelin Acetate inducing double ovulation and Scoggin et al. (2002) with 12.5mg EPE reporting $67.6 \%$ embryos recovery rate.

\section{Conclusion}

After evaluating the results, we can conclude that the treatment using 8.0mg EPE increased the incidence of double ovulation, with a tendency to higher embryos recovery rate per cycle. In view of this, this treatment might be considered an alternative to improve the results of the equine embryo transfers program.

\section{Acknowledgements}

To Fundação Carlos Chagas Filho de Amparo à Pesquisa do Estado do Rio de Janeiro (FAPERJ) for financial support.

\section{References}

Alvarenga, M. A., Carmo, M. T., \& Landim-Alvarenga, F. C. (2008). Superovulation in mares: limitations and perspectives. Pferdeheilkunde, 24(1), 88-91. http://dx.doi.org/10.21836/PEM20080118.

Alvarenga, M. A., McCue, P. M., Bruemmer, J., Neves Neto, J. R., \& Squire, E. L. (2001). Ovarian superstimulatory response and embryo production in mares treated with equine pituitary extract twice daily. Theriogenology, 56(5), 879-887. http://dx.doi.org/10.1016/S0093-691X(01)00615-X. PMid:11665889.

Azevedo, M. V., Souza, N. M., Ferreira-Silva, J. C., Batista, I. O., Moura, M. T., Oliveira, M A L., Alvarenga, M. A., \& Lima, P. F. (2015). Induction of multiple ovulations in mares using low doses of GnRH agonist Deslorelin Acetate at 48 hours after luteolysis. Pferdeheilkunde, 31(2), 160-164. http://dx.doi.org/10.21836/PEM20150208.

Bertozzo, B. R., Sampaio, B. F. B., Bender, E. S. C., Pagnoncelli, R. R., Silva, E. V. C., \& Zúccari, C. E. S. N. (2012). Estratégias e entraves na superovulação de éguas. Veterinária em Foco, 10, 26-33.

Bonin, D. F., Dell'Aqua Junior, J. A., Fioratti, E. G., \& Alvarenga, M. A. (2010). Efeito do tratamento com Extrato de Pituitária Equina na resposta ovariana e eficiência reprodutiva de éguas idosas em programa de transferência de embriões. Veterinária e Zootecnia, 17, 94-103.

Cullingford, E. L., Squires, E. L., Mccue, P. M., \& Seidel Junior, G. E. (2010). Attempts at superovulation of mares with porcine follicle stimulating hormone and recombinant equine follicle stimulating hormone. Journal of Equine Veterinary Science, 30(6), 305-309. http://dx.doi.org/10.1016/i.jevs.2010.04.006.

Dippert, K. D., Jasko, D. J., Seidel Junior, G. E., \& Squires, E. L. (1994). Fertilization rates in superovulated and spontaneously ovulating mares. Theriogenology, 41(7), 1411-1423. http://dx.doi.org/10.1016/0093-691X(94)90192-L. PMid:16727495.

Douglas, R. H. (1979). Review of induction of superovulation and embryo transfer in the equine. Theriogenology, 11(1), 33-46. http://dx.doi.org/10.1016/S0093-691X(79)80016-3.

Farquhar, V. J., McCue, P.M., Vanderwall, D. K., \& Squires, E. L. (2000). Efficacy of the gnrh agonist deslorelin acetate for inducing ovulation in mares relative to age of mare and season. Journal of Equine Veterinary Science, 20(11), 722-725. http://dx.doi.org/10.1016/S0737-0806(00)80183-5.

Ginther, O. J., \& Pierson, R. A. (1989). Regular and irregular characteristics of ovulation and the interovulatory interval in mares. Journal of Equine Veterinary Science, 9(1), 4-12. http://dx.doi.org/10.1016/S0737-0806(89)80110-8.

Köllmann, M., Probst, J., Baackmann, C., Klewitz, J., Squires, E. L., \& Sieme, H. (2008). Embryogewinnungsrate nach Superovulation mit equinem Hypophysenextrakt (eFSH ${ }^{\circledR}$ ) bei der Stute. Pferdeheilkunde, 24, 397-405.

Logan, N. L., Mccue, P. M., Alonso, M. A., \& Squires, E. L. (2007). Evaluation of three equine FSH superovulation protocols in mares. Animal Reproduction Science, 102(1-2), 48-55.http://dx.doi.org/10.1016/j.anireprosci.2006.09.027. PMid:17188438.

Machado, M. S., Arantes, M., Peres, K. R., Leão, K. M., Carmo, M. T., Squires, E. L., \& Alvarenga, M. A. (2003). Dinâmica folicular, número de ovulações e embriões recuperados em éguas submetidas a tratamento superovulatório, utilizando-se extrato de pituitátia eqüina e FSh eqüino purificado. Revista Brasileira de Medicina Veterinária, 27, 506-508.

McCue, P. M. (1996). Superovulation. Veterinary Clinics: Equine Practice, 12(1), 1-11. http://dx.doi.org/10.1016/ S0749-0739(17)30291-2. PMid:8726446.

McCue, P. M., \& Squires, E. L. (2015). Equine embryo transfer. 1st ed. Tenton newmedia. http://dx.doi.org/10.1201/ b18123.

Nagao, J. F., Neves Neto, J. R., Papa, F. O., Alvarenga, M. A., Freitas-Dell'Aqua, C. P., \& Dell'Aqua, J. A. (2012). Induction of double ovulation in mares using Deslorelin Acetate. Animal Reproduction Science, 136(1-2), 69-73. http:// dx.doi.org/10.1016/j.anireprosci.2012.10.015. PMid:23182475. 
Scoggin, C. F., Meira, C., McCue, P. M., Carnevale, E. M., Nett, T. M., \& Squires, E. L. (2002). Strategies to improve the ovarian response to equine pituitary extract in cyclic mares. Theriogenology, 58(1), 151-164. http://dx.doi. org/10.1016/S0093-691X(02)00902-0. PMid:12182358.

Squires, E. L., Carnevale, E. M., Mccue, P. M., \& Bruemmer, J. E. (2003). Embryo technologies in the horse. Theriogenology, 59(1), 151-170. http://dx.doi.org/10.1016/S0093-691X(02)01268-2. PMid:12499026.

Squires, E. L., Mckinnon, A. O., Carnevale, E. M., Morris, R. P., \& Nett, T. M. (1987). Reproductive characteristics of spontaneous single and double ovulating mares and superovulated mares. Journal of Reproduction and Fertility. Supplement, 35, 399-403. PMid:3479594.

Woods, G. L., \& Ginther, O. J. (1983). Induction of multiple ovulations during the ovulatory season in mares. Theriogenology, 20(3), 347-355. http://dx.doi.org/10.1016/0093-691X(83)90068-7. PMid:16725850. 